\title{
The Loss of Language ${ }^{i}$
}

\author{
Teresa C. Luciani
}

\begin{abstract}
Cet article commence par un extrait d'un chapitre de Cristina, un roman en cours d'écriture. Centré sur la relation entre une mère, Lucia Fiume, et sa fille, Cristina, le chapitre "Antipasto Tre Colore I» explore les tensions entourant la façon dont la perte de la " langue maternelle " de Cristina, ainsi que les différences générationnelles, compliquent la communication avec les femmes de sa famille. J'enchaîne avec un essai personnel intitulé "Tongue-tied 》. En $y$ imbriquant des mots d'autres auteurs, je cherche un sens à la perte de ma "langue maternelle » et aux conséquences de cette perte.
\end{abstract}

\section{Prologue}

Stories are how I make sense of my experiences and the world around me, how I play with language. I mix up the ways in which I tell stories: fiction, personal essay, poetry, photography; it depends on what I am trying to convey, along with how the story wants to be told. In this particular text I experiment with fiction and the personal essay as a way to voice my struggles with language.

This article begins with an excerpt from a chapter in Cristina, a novel-inprogress. Centered around the relationship between a mother, Lucia Fiume, and her daughter, Cristina, the chapter "Antipasto Tre Colore I" explores the tensions surrounding how the loss of Cristina's 'mother tongue,' along with generational differences, complicates communication with her female relations. I then move to the personnal essay, entitled "Tongue-tied." Interwoven with words from other writers, I attend to how I make sense of losing my 'mother tongue' and the consequences of this loss.

\section{Antipasto Tre Colore I}

Cristina drags a sac of potatoes from the laundry room to the kitchen table, dumps it next to the dishwasher, then races back to the laundry room-there are more things to gather and her aunts will be arriving any minute. From the fridge, tucked in a corner of the laundry room, Cristina pulls out everything she sees: four celery stalks, four bags of carrots, four bags of fresh green beans, four heads of cauliflower. There's too much to carry all at once. She twists around in search of something she might use to help her transport the vegetables. There, next to the washing machine, is a bagnarola that doubles as a miniature washing tub. Long, wide and sturdy, it will fit more than what Cristina can hold in her hands. One by one, she tosses in the vegetables-there's still some room. Scurrying to the cantina, she scans the shelves for more ingredients.

"Ma," Cristina shouts. "Tuna and tomato paste. What else?"

Lucia calls out the remaining ingredients, each found in jars or cans. "Prend' i funghi e le olive con pimento," her voice rises as her patience drops, 
"cipolle sottoaceto—ma, quelle piccoline. E peperoni arrosti, quelli che abbiamo fatto l'anno scorso." quattro."

As Cristina reaches for the tuna, Lucia says, "Ricordati, sempre in

The bagnarola increases in weight. Too heavy to drag, she kicks it with her foot like a soccer ball. Inch by inch, Cristina and the bagnarola skid their way into the kitchen.

Noise from a distance grows closer. Voices. The screen door at the side of the house creaks open.

"Lu-ci!" a woman hollers from the top of the stairs.

They have arrived.

"Vieni, vieni giù. Stonga qui." Lucia responds.

One by one the women enter the house, climb down the stairs and greet Lucia. Their husbands remain outside, wandering up and down the driveway, lost and confused as they seek out Luca, Cristina's father, who is nowhere to be found.

"Lu-ci!" Zia Gabriela hollers again, her arms open wide. They hug and kiss each other on both cheeks.

"Cia!" Zia Serafina says while pecking her sister-in-law on the cheeks.

"Lu-e!" Zia Daniela squeezes her arms tightly around Lucia's neck.

"Lu-lu," Zia Mariagrazia murmurs between kisses and hugs.

Each woman addresses her sister-in-law with an abbreviated version of the name Lucia, a sort of nickname only she uses. From across a crowded grocery store, a busy street, Lucia may not see her sister-in-law in the distance, but she knows exactly who is calling her.

One more woman arrives: Rosamaria from the factory. She greets Lucia with kisses.

Zie Gabriela, Serafina, Mariagrazia and Daniela have come for a visit from Toronto, Ontario. Arriving two nights ago, they are staying at their uncle Nunzio's house in Burford, a small town only a short drive away from Brantford. They are here not only to fare una visita a Lucia e chiacchierare, but to also dare una mano because they all know it takes many hands to make a good jar of antipasto and today there are plenty.

"Dov'è Cristina?" Rosamaria asks.

"Sta al bagno." Lucia replies.

When these women are together few words of English pass their lips because English words fall flat on their tongues, feel stiff and heavy. They prefer, instead, to speak in dialect, a local language comprised of words and expressions that taste familiar, that roll around their tongues with ease, that fill up their conversations with double meanings, layered meanings, many meanings. When they speak to Cristina, however, they mix in English with their dialect, creating awkward sentences that get stuck between their teeth, are difficult to spit out.

"Ah, bella mia. How it dhat you do today?" Zia Daniela asks as soon as Cristina appears.

Cristina no longer speaks this dialect, her mother tongue; it is a language long forgotten, no longer hers. Though she cannot speak their language, she 
knows it instinctually, feels it in her bones as their voices seep into her skin, as their tongues curl around every letter, as their lips stretch around the fullness of each word. But Cristina's lips, her tongue, tight and flat, can't seem to wrap around their words-she is tongue-tied by their language. So she speaks to them in another language, the one she learned at school-English. With her words, some gestures, along with the help of her mother, Cristina makes herself understood. And the women? They fill in the spaces with whatever is at hand-an object, a facial expression, anything to move along the sentence, help them make sense of what at first may seem like nonsense. What is remarkable is that they do this language dance each time, knowing deep down that words are slippery, difficult to grasp; yet they still reach out for Cristina's words as best as they can, even as they feel those words slipping through their fingers.

"Fine, Zia," Cristina replies, forcing a grin.

The women respond with big and wide smiles that reveal teeth that are missing, yellowed, cracked. They turn toward each other, form a circle and coo to one another as they speak their good wishes for Cristina. "Che bella ragazzina." "Sì, sì. Guarda che occhi verdi c'ha!" "Ė bella rotunda, pure. C'è un po' di carne." "Che bella mogli' fa." "Sì, sì, davvero. Che fortuna ha quell'uomo che la piglia." "E che bei figli fa."

When the women finish fanning Cristina with their praises and predictions, they flock around their little treasure, pinching and prodding her with their fingers, pecking each cheek with their dry, coarse lips. Cristina hates being smothered like this every time her aunts come to visit; she has to get away. Ah, the perfect escape: a space between Zia Serafina's legs. Cristina crawls her way through, dashes to the bathroom, locks the door behind her.

Facing the mirror, she inspects her body. Her arms and cheeks are covered in red marks. Like blisters from a sunburn her skin stings. Gritting her teeth, she plunks down on the toilet seat, rests her elbows on her knees, her fists under her cheeks and wishes them away, far away.

\section{Tongue-tied}

I struggle to speak the language of my childhood, a language specific to our household, a language composed of letters and sentences that struck my ear with a particular rhythm and roundness, that rolled from our tongues like sap from a tree-rich and sweet to the tongue. That lulled me to sleep like waves lapping against the shore-soft and warm to the touch. What might have sounded out of tune to others was not out of tune to me: these were our sounds, our words, our tongue. "We want to be at home in our tongue. We want to be able to give voice accurately and fully to ourselves and our sense of the world" (Hoffman, 124). When we spoke, we (re)connected to the past, to a place an ocean away, and we made sense of our lives in the present. "I belonged to a people who lived across the ocean; people who spoke no English, whose language had room to enfold me" (Hansen, 23).

A language of the everyday, my mother also made up words to make herself understood. Emerging from the situation at hand, her words were 
accompanied by the pitch of her voice, the curve of her hand, the look in her eyes. These signs, ephemeral and playful, added texture to her thoughts, weight to her wit, sweetness to her imagination. And they were all mine to learn and to understand. "We seek to make a place for intimacy. Unable to find such a place in standard English, we create the ruptured, broken, unruly speech of the vernacular" (hooks, 175).

I don't know when I stopped speaking to my mother in our special language. She tells me when I began kindergarten. So soon? What was it that made me hold my mother tongue in perpetual suspension? Take up another language not my own, not spoken in our household, and present it as the only way I communicated with her? Why couldn't I speak both languages: English at school and our language at home? Why did I choose English over my (m)other tongue?

(Anzaldúa, 59).

“. . . if you really want to hurt me, talk badly about my language"

Miss Harvey, our Grade Three English teacher, writes the word "church" on the blackboard.

"Class, who can pronounce this word?" she asks. "It's in this week's Spelling Book chapter. Class, did everyone study this week's words?"

We all nod in agreement to avoid her piercing glare of disapproval.

"Well, then, if everyone has prepared for this lesson, this word should be easy. Correct?" Miss Harvey scans the room for her first victim of the morning.

Tara and Sara Smith's hands immediately shoot up. Sitting upright in perfect posture, feet flat on the floor and knees touching, Tara and Sara are dressed in crisp white blouses, navy skirts and black patent shoes with a buckle. They look and act more like twins than cousins. "I know, Miss Harvey," Sara says in a whiny voice. "I know, I know. Pick me," Tara squeals. They always know the words Miss Harvey writes on the blackboard, and giggle when anyone else makes a mistake.

Miss Harvey glosses over the two girls, searches for a quieter student.

I've never seen that word before. Don't want to get laughed at so I write the word in my notebook over and over again, never looking up.

"Tracy," Miss Harvey never calls me by my given name, Teresa. "Can you pronounce the word I just wrote on the blackboard? And then use the word in a sentence."

My mind goes blank. Can't even guess. I've never seen that word before. What could it mean? Maybe if I pronounce it that will be good enough and she'll ask someone else for a sentence. I slice the word in half, c-h-u, then, r-c-h. In Italian, ch is sometimes pronounced like a hard $\mathrm{c}$. I begin with the first part, " $\mathrm{C}$. .. c..."

Tara and Sara giggle in the background.

My cheeks flush a deep red. I must be wrong. I studied the whole chapter, twice, and I can't remember this word.

I start again, my foot rapidly tapping the gray wall-to-wall carpet. "C, c ..." 
Miss Harvey keeps quiet, does not relinquish any hints.

"Courque." I say.

Tara and Sara laugh louder.

Miss Harvey huffs in frustration. "No, no, Tracy. That's wrong. The word is pronounced," she opens her mouth wide, fully exposing her pearly white teeth, "CHuurCH." Miss Harvey then clears her throat, adjusts her glasses. "I assume then, Tracy, that if you don't know this word, then you can't say it in a sentence, either. Is this correct?"

I shake my head side to side.

"Well, then. How about someone else in the class who studied this week's vocabulary say this word for us. Yes, Sara. Please tell us how to pronounce this word."

I cannot hear Sara's voice, do not learn how she pronounces the word. I hear only the echo of their laughter.

For the rest of English class I keep my head down, scribble illegible words all over the pages of my notebook.

When I am home, I pass through the kitchen on my way to my bedroom. $\mathrm{Ma}$ is peeling potatoes over the sink. spelling.

"Ciao, Teresa." She rarely speaks to me in English. Can't help me with my

I do not reply. Instead I race to my bedroom, slam the door shut and open up the Canadian English Dictionary. The one I borrowed from school.

When I was not in the kitchen, I could be found in my bedroom studying the English dictionary. Each night, I forced myself to learn at least five new words, randomly selected. I memorized the spelling, pronunciation, definitions and any sentences offered as examples for each word. By the end of the week, I tested my memory with my own quizzes and passed them with flying colours. My accent, as well, evident the minute I opened my mouth, slowly disappeared until there was no trace of difference. With each word, each test, I sounded more and more Canadian. "Perhaps I've read, written, eaten enough words so that English now flows in my bloodstream" (Hoffman, 243).

With an enlarged vocabulary, English tests were a cinch. I often won the spelling bee in my class and wrote A plus assignments. English became my favourite subject. Had we not moved to Toronto two months before my elementary school graduation, I would have been presented with the English award. Had my Grade Thirteen English teacher not moved away late in the term, I would have also been presented with the English award at my high school graduation. I really wanted those awards as proof of my mastering the English language, but knowing I was supposed to get them was good enough for me.

It's no surprise, then, that my undergraduate degree major is in English (along with Anthropology - but that's another story). I could never get enough of Shakespeare, Wordsworth, Dickens, Lawrence. Play after play, poem after poem, 
novel after novel, I learned more and more words: longer, more sophisticated and complex, these words were worth their weight in gold. I enjoyed using them at school and at home. I felt proud of my pronunciation-no hint of an accent. At school, classmates and professors knew of what I was speaking. At home, no one had a clue. But that didn't stop me from using these twenty-five cent words in front of my mother.

It would be years later when I first learn of my mother's experience in formal education. It's a short story. In Italy, Ma left school in Grade Five to work in the fields with her father and brothers. When she immigrated to Toronto, at the age of nineteen, school was not an option unless she found a girlfriend to accompany her. Young women just didn't walk the streets alone in those days, I was told. Ma, overwhelmed by her new environment, never found a friend to walk her to school. So she went to work instead. Apparently taking the bus alone to work was acceptable.

Then marriage happened, followed by the first child, my brother. There was no time for English. Within her circle of friends and family, including coworkers at the factories where she worked who were also Italian, no one spoke English. Her life in Toronto was lived and breathed in Italian.

Only when my parents moved to Brantford, Ontario was Ma forced to learn English-but not formally. Ma taught herself how to speak English by listening to the news on the radio and by watching soap operas on television. Reading and writing were obstacles to be tackled at another time, when the children are older.

That time never came.

". . . for most/the dream/did not come easily/the golden paved North America/wasn't paved at all" (Patriarca, 47).

Lying on my bed, with the door closed, I'm finishing up my assignment on Shakespeare's Sonnet Eighteen for my Grade Eight English class. I've written five drafts, all by hand, and I'm starting my sixth. I want it to be perfect. And perfection takes time.

Ma opens the door without knocking. She holds a letter in her hand.

"Trezee." Ma calls me more and more by my Anglicized name finally. I refuse to be addressed by the name Teresa. It has taken her a long time to make the adjustment. When she slips up, I quickly remind her.

"What? Can't you see? I'm busy."

"No get angry." Her voice is slow and gentle. When she speaks to me this way, I know she wants something. "I need you to do me a favur," she says.

"What is it this time?" I huff.

She moves closer, sits down on the edge of my bed. "Dhis is de form fer my medication. Can you do this fer me?" 
My father has a medical/dental plan at work that covers my mother's stockpile of medication: high blood pressure pills, cholesterol pills, thyroid pills, calcium supplements, vials of insulin, needles, blood-glucose test strips--the list goes on. But she has to pay for everything upfront at the pharmacy, then fill out a reimbursement form and wait two to four weeks for a cheque from the insurance company. The form is dense, requests a lot of personal information, all to be handwritten between narrow lines and in tiny boxes. Ma does not feel confident in her writing skills, always afraid she will get it wrong, mess something up and delay the reimbursement. She needs the money soon. The bills are piling up, there's always more medicine to refill, food to buy-the list goes on.

When it comes to forms and letters, I'm always the one she goes to for help-camouflaged as a favour. Where is my brother? Or my sister? Why can't she bother them and not me? Why is it always me?

"Ma, why can't you do it yourself? I've got a lot of work to do." me."

She pauses for a moment, then peers into my eyes. "Please do dhis fer

I feel like she is begging, and begging makes me feel guilty. I don't want to feel guilty. Damn it! Why can't she just learn how to write in English like I did!?

"Ma-"

She doesn't let me finish my sentence, knows what I'm about to say. Ma rises from my bed, shuffles her feet as she heads to the door. "Dhat's okay. You finish yur work." She folds the piece of paper in half, runs her fingers over the crease. "I find somebody else. No worry. Go back to work," she adds and closes the door behind her.

"Damn it!" I punch the mattress with my fist. "Why does she always do this to me?!" I stare at my fist for a long time; slowly my fingers unfurl. I pick up my pen again and return to my assignment; but when I reach the edge of the paper my hand stops moving. "Damn it!" I whip my pen across the room, it smacks against the door. "Fine! I'll do it!" I holler and wait for her return.

\section{Notes}

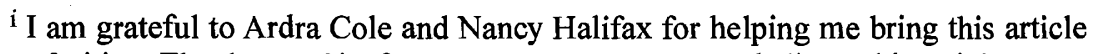
to fruition. Thank you, Sis, for your constant support. I dedicate this article to my mother-Sempre per te. Ti voglio tanto bene, Mammina. 


\section{$86 \cdot$ Tessera}

\section{Works Cited}

Anzaldúa, G. Borderlands/La Frontera: The New Mestiza. San Francisco: Aunt Lute Books, 1987.

Hansen, V. "Women of Letters: Stories Breathed to Me by My Mother." Our Grandmothers, Ourselves. Ed. Gina Valle. Vancouver: Raincoast Press, 1999. 21-28. Hoffman, E. Lost in Translation: A Life in a New Language. New York: E. P. Dutton, 1989.

hooks, b. Teaching to Transgress: Education as the Practice of Freedom. New York: Routledge, 1994.

Patriarca, G. "Dolce-Amaro." In Italian Women and Other Tragedies. Toronto: Guernica, 1999. 47-48. Third printing. 